\title{
Schistosoma mansoni granuloma in late evolutive phase, in a case of tumoral form in man
}

\author{
Pedro Raso ${ }^{[1]}$, Leonardo Arruda Moraes Raso ${ }^{[1]}$, Ferdinan de Almeida Melo ${ }^{[2]}$ and Wagner Luiz Tafuri ${ }^{[2]}$
}

\begin{abstract}
[1]. Departamento de Anatomia Patológica e Medicina Legal, Faculdade de Medicina, Universidade Federal de Minas Gerais, Belo Horizonte, MG. [2]. Departamento de Patologia
\end{abstract} Geral, Instituto de Ciências Biológicas, Universidade Federal de Minas Gerais, Belo Horizonte, MG.

\section{ABSTRACT}

Introduction: Authors describe human schistosomal granuloma in late chronic phase, from the morphological and evolutionary viewpoints. Methods: The study was based on a histological analysis of two fragments obtained from a surgical biopsy of peritoneum and large intestine of a 42-year-old patient, with a pseudotumoral form mimicking a peritoneal carcinomatosis associated to the schistosomiasis hepatointestinal form. Results: Two hundred and three granulomas were identified in the pseudotumor and 27 in the intestinal biopsy, with similar morphological features, most in the late chronic phase, in fibrotic healing. A new structural classification was suggested for granulomas: zone 1 (internal), 2 (intermediate) and 3 (external). Conclusions: Regarding granuloma as a whole, we may conclude that fibrosis is likely to be controlled by different and independent mechanisms in the three zones of the granuloma. Lamellar fibrosis in zone 3 seems to be controlled by matrix mesenchymal cells (fibroblasts and myoepithelial cells) and by inflammatory exudate cells (lymphocytes, plasmocytes, neutrophils, eosinophils). Annular fibrosis in zone 2, comprising a dense fibrous connective tissue, with few cells in the advanced phase, would be controlled by epithelioid cells involving zone 1 in recent granulomas. In zone 1, replacing periovular necrosis, an initialy loose and tracery connective neoformation, housing stellate cells or with fusiform nuclei, a dense paucicellular nodular connctive tissue emerges, probably induced by fibroblasts. In several granulomas, one of the zones is missing and granuloma is represented by two of them: Z3 and Z2, Z3 and Z1 or Z2 and Z1 and, ultimately, by a scar.

Keywords: Schistosomiasis mansoni. Granuloma. Morphology. Evolution and pseudotumor form. Modulation of granuloma.

\section{INTRODUCTION}

Granulomas are nodular formations in which exudate cells are displayed in particular arrangements to the inflammatory focus, forming structures with peculiar aspects and architecture which frequently allow to diagnose the disease even without finding its causal agent. Macrophages and their derivatives (remarkably epithelioid and giants cells) and lymphoid cells and their derivatives (particularly plasma cells) comprise the required cells. Accessory cells are composed of eosinophil granulocytes which may, in certain cases, prevail over the other cells, so that granulomas arise almost exclusively eosinophilic as it is seen during the early acute phase of schistosomiasis toxemic form. In other cases, neutrophil granulocytes may prevail, developing an abscess (more common in paracoccidioidomycosis; rare in schistosomiasis); exceptionally mast cells and basophils may also contribute as accessory cells. Fibroblasts embedded are constantly found in an extracellular matrix composed of fibronectin, laminin, glycosaminoglycans and collagens ${ }^{1,2}$.

Granulomatous reaction in schistosomiasis is a late T-dependent hypersensitivity response to soluble egg antigens (SEA) released by a mature miracidium (this becomes mature in six to eight days after egg deposition), which induce a marked Th2 protective immune response, which guides the granulomatous reaction. Recent studies have indicated that IL-13 receptor $\alpha 2$ (IL-13 R $\alpha 2$ ) secreted by TCD4+ cells type 2 is the main mediator for granulomatous response and for hepatic fibrosis, which are two fundamental lesions in schistosomiasis ${ }^{3}$.

Address to: Prof. Wagner Luiz Tafuri. Depto de Patologia Geral/IC/UFMG. Av. Antônio Carlos 6627, Pampulha 31270-901 Belo Horizonte, MG, Brasil.

Phone: 5531 3409-2889

e-mail: wagnertafuri@gmail.com

Received in 31/01/2012

Accepted in 31/08/2012
It has long been observed in humans $\mathrm{s}^{4-7}$ and in laboratory animals, specially in mice ${ }^{8-10}$, that as the schistosomiasis infection evolves and two changes become evident in granulomas formed around an egg: a) their volume decreases gradually to a point where they are replaced by a scar and $b$ ) as the granulomas evolve they change as for their appearance and the amount of cells around the egg. This phenomenon is termed immunomodulation or simply modulation and depends on the participation of T-cell subpopulations and on immunosuppressive serum factors acting among themselves ${ }^{8}$.

Cases reported in the literature have clearly shown the modulation of granulomatous response, starting with around 70-78 days, and concluded, in some cases, within 150-day infection, when this is indistinguishable from other chronic forms $\mathrm{s}^{4,5}$. Thus, the purpose of this work was to study morphological and evolutive aspects of granulomas in the late evolutive phase, in a patient with the tumor or pseudotumor form of abdominal schistosomiasis mansoni.

\section{METHODS}

This study was conducted in two fragments obtained from a surgical biopsy of lesions from the large intestines and from the peritoneum (B12.369/03), of a 42-year-old male patient (E.F.S), admitted at Hospital da Criança São José, Contagem/MG with a tumor form of schistosomiasis mansoni, with clinical signs and symptoms of intestinal obstruction, mimicking neoplasms. Fragments were whitish, irregular, with a firm consistency and measured $4.0 \times 2.5 \times 1.5 \mathrm{~cm}$ (peritoneum) and $1.0 \mathrm{x}$ $0.8 \times 0.4 \mathrm{~cm}$ (large intestines), respectively. After fixed in formaldehyde $(10 \%)$, they were processed and included in paraffin blocks. Blocks were cut at 4 micrometers which were stained by hematoxylin and eosin (HE), Gomori trichrome and by picrosirius red, according to the technique recommended by Junqueira et al. ${ }^{11}$. A yellowish fragment of a hepatic biopsy, measuring $0.2 \times 0.4 \mathrm{~cm}$, was examined. 


\section{RESULTS}

At the late evolutive phase, a large number of granulomas has three distinct and morphologically different zones: I) zone 1, central; II) zone 2, intermediate; III) zone 3, peripheral, which modifies, due to the time of evolution.

\section{Central zone (zone 1)}

In early phases, it is generally the longest and the less stained both by $\mathrm{HE}$ and by special staining such as Gomori trichrome and picrosirius. It frequently houses the embryonated egg or its shell, whether or not surrounded by an eosinophilic amorphous area of necrosis, and by a thin fibrillar substance, mixed with few starry cells resembling fibroblasts or by cells with fusiform nuclei and macrophages (Figures 1A and 1B). This amorphous eosinophilic material, also seen in the early evolutive phase of the acute phase of schistosomiasis (necrotic-exudative granulomas) around the egg, known as Hoeppli phenomenon, contains egg antigens, host immunoglobulins ${ }^{12}$ and fibronectin (non-collagen glycoprotein) with a high molecular weight produced by fibroblasts and by other mesenchymal cells ${ }^{13,14}$. In this phase, zones 2 and 3 are already distinct, as it will be discussed later. In granulomas with no eggs, the necrosis zone, responsible for the Hoeppli phenomenon is not identified. The same occurs when they are centered by the empty shell or egg debris.

In older granulomas (posterior phase to that previously described), they enter the productive phase. In this phase, the necrosis zone tends to disappear and the egg or its shell is partially or completely involved by one or more Langhans giant cells or foreign body giant cells (Figures 1C and 1D). This aspect also became evident during the acute phase in granulomas with 70 to 90 days of evolution ${ }^{4}$. When stained with picrosirius, thin conjunctive fibers, stained in green, start to appear intermingling fibroblasts and histiocytes, indicating a type-III collagen. In the third phase, zone 1, the central one, is replaced by a homogeneous little cell mass, stained in dark green by Gomori, semicompact with empty spaces or completely compact. Therefore, centrifugal fibrosis occurred from inside to outside. Few or no fibroblasts and histiocytes are seen replaced by a dense fibrous nodule (Figure 1E). These results seem to confirm findings described by Al Adnani ${ }^{13}$ of decreased fibronectin, due to decrease or absence of cells which are able to produce it (macrophages and fibroblasts) ${ }^{15}$.

\section{Intermediate zone (zone 2)}

Its thickness is variable and it is present and is part of acutephase granulomas in the acute phase of schistosomiasis. In the same initial period, between 45 and 78 days after infection, it appears as a crown completely involving zone 1 . In this phase it is mainly composed of epithelioid histiocytes. As time passes, cellularity is reduced and gives rise to an acidophilus zone to $\mathrm{HE}$ and greenish stain by Gomori. It tends to be a layer composed of collagen fibers, with a variable thickness, sometimes homogeneous or composed of round and parallel fibers type-3 prevailing over those of type- 1 collagen (Figures 1A, 1B, 1F and 1G). Based on the early constitution of epithelioid histiocytes, the resulting collagen is thought to be produced mainly by these cells. These morphological data are in accordance with the findings of Linder et al. ${ }^{15}$, i.e., the absence of fibronectin from the reduction or the absence of cells (macrophages and fibroblasts)
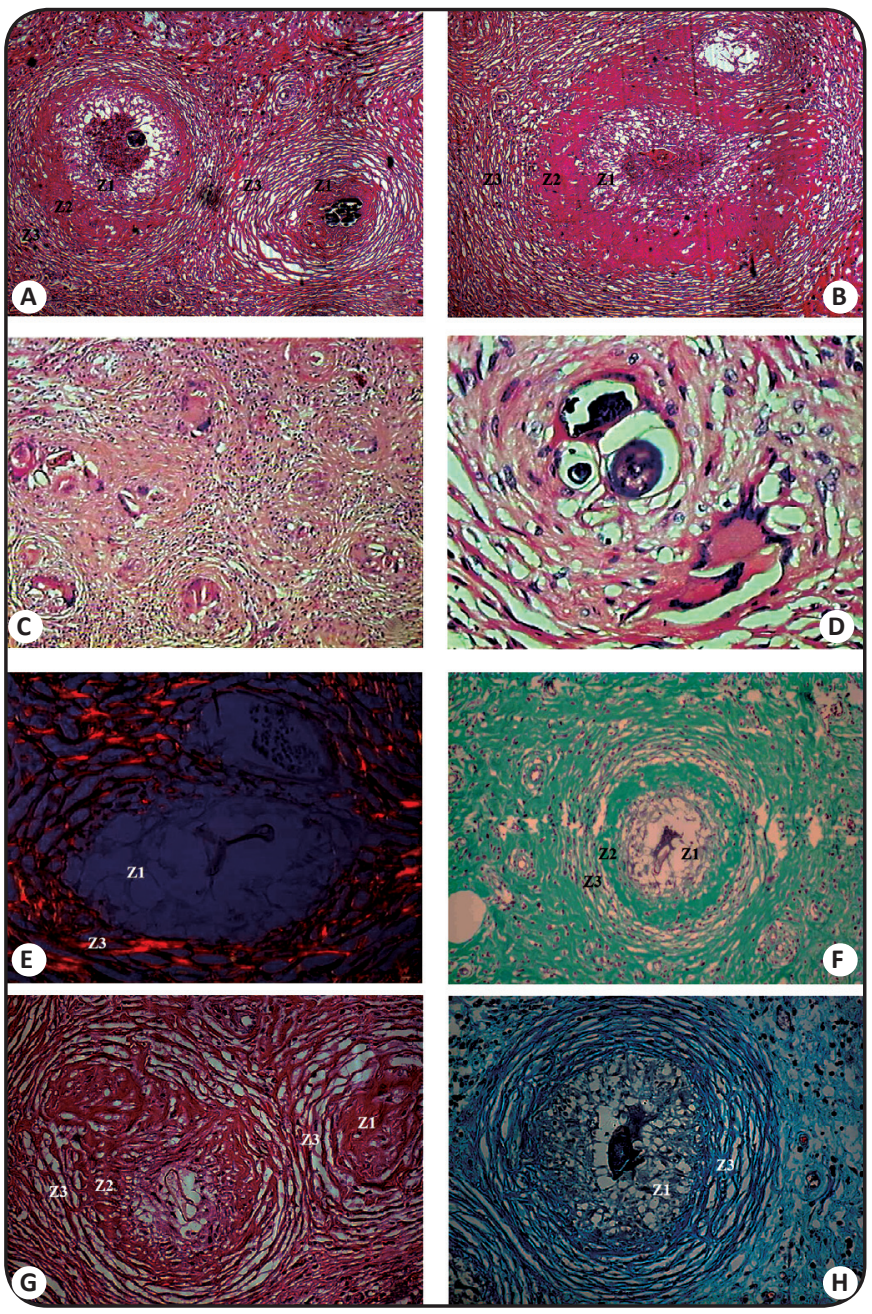

FIGURE 1 - Pseudotumoral form of Schistosoma mansoni, showing the morphological aspect of granulomas in various stages of healing by fibrosis. A: On the left, granuloma in healing evolutive phase with central necrosis surrounding the egg (zone 1). On the right, fibrosis of zone 1 and 3 surrounding calcified eggs (HE, 10x). B: Granuloma with central necrosis. Fibrosis of zone 2 and 3 (HE, 10x). C: Various granulomas in productive phase, with Langhans giant cells or a foreign body and in fibrosis healing (HE, 10x). D: Granuloma in fibrotic healing phase, substituting central, intermediate and external zones for collagen fibers. Giant cells and fusiform cells morphologically similar to fibroblasts. In the external zone, thicker fibers like druses in onion scales (HE, 40x). E: Granuloma is totally fibrosed. The three zones, mainly 1 and 2, form a compact mass around the remnant of an egg. In the peripheral zone, zone 3, conjunctive fibers form dense structures, joined together as links in a chain, but separated by an amorphous substance (Picrosirius, 40x). F: Granuloma with three distinct zones. Zone 1 has thin conjunctive fibrils, with a lacy appearance, involving remnant of an egg. Zone 2 was substituted by a dense conjunctive tissue, with few cells, stained in Green by Gomori trichrome. In zone 3, the conjunctive tissue is lamellar (Gomori, 20x). G: Fibrosis of zone 2 and 3 on the bigger granuloma. Fibrosis of zone 1 and 3 on the smaller granuloma (HE, 20x). H: Granuloma with two distinct zones. Zone 1 has thin conjunctive fibrils, with a lacy appearance, involving remnant of an egg. In zone 3 , the conjunctive tissue is lamellar (Gomori, 20x).

producing this glycoprotein. We believe this range, which is initially cellular and eventually practically fibrous and acellular, might play an important role as a barrier to the SEA diffusion through egg pores to limit the lesion.

\section{External zone (zone 3)}

According to our experience with acute toxemic form in humans ${ }^{4}$, this zone is well delineated mainly in granulomas with over $120-150$ 
days of evolution (granulomas in fibrotic healing phase). It is mainly formed by type-I collagen fibers and a smaller amount of type-III collagen, well evidentiated by picrosirius and by Gomori trichrome stainings, forming thicker fibers, parallel and round with a few overlapped cells interwoven with twines, resembling druses in onion scales, externally involving zone 2 (Figures 1A, 1B, 1F and 1G). In older and smaller granulomas when zone 2 tends to vanish or disappear, it may directly involve zone 1 (Figures $\mathbf{1 E}$ and $\mathbf{1 H}$ ). Sometimes, when there is a confluence of granulomas, it starts to form a single mantle involving or limiting two or more granulomatous formations. This external zone (zone 3 ) is thought to be produced by mesenchymal cells (fibroblasts, myofibroblasts, histiocytes, plasmocytes and eosinophils) present and abundant in recent granulomas (necrotic-exudative granulomas and exudative granulomas). Therefore, it has a centripetal formation (from outside to inside).

\section{Fibrotic granulomas}

Since the disease evolves to the chronic form, as a result of the modulation, granulomas tend to slowly reduce its size, until they become a small fibrotic nodule, consisting almost exclusively of collagen fibers, paucicellular or practically acellular, similar to a scar (Figure 1C). This aspect is seen in lesions with years of evolution. The transformation occurs by replacing zone 1 with an amorphous acidophilic mass, compact and more stained, which lies in the center of the lesion (Figures $1 \mathrm{E}$ and $1 \mathrm{G}$ ), followed by the disappearance of zone 2, previously well-delineated and by the withdrawal of zone 3. It eventually ends up as a lesion either regular or not, consisting exclusively of collagen fibers, predominantly of type 1 , when fibronectin is no longer detected ${ }^{15}$.

Granulomas of the large intestine have the same characteristics described in pseudotumoral form.

Histological analysis of hepatic biopsy has shown a granuloma in fibrotic healing phase, with the external zone delineated by parallel and circular connective fibers like druses in onion scales, as a result of modulation, and a discreet inflammatory infiltrate of mononuclear cells in portal tracts, regardless the granulomatous lesion. Portal fibrosis caused by Schistosoma mansoni eggs was also discreet. The Symmers-Bogliolo form of disease was discarded. Hepatocytes have shown a marked and diffuse non-alcoholic steatosis.

\section{DISCUSSION}

Examining a large number of granulomas in the peritoneum (around 203) and in the serosa and external muscular tissue of the large intestine (27), in the same individual, E.F.C., 42 years old, from Belo Horizonte (MG), with a tumor or pseudotumoral form of schistosomiasis mansoni, provided a favorable view of the morphology of granulomas in their several evolutive phases in humans.

Both in the peritoneum and in the large intestines (LI), granulomas were in several evolutive phases (recent, old and scarred), which indicates an active long-lasting disease, probably lasting for years and modulated, with egg deposition at different stages. Although worms or their remains were not identified in the sections examined, eggs are believed to have been deposited in situ, both in the peritoneum and in the LI. In this case, we would have to assume that single and mated females would have gone from their natural habitat to the peritoneum, through aberrant venous branches or connections between mesenteric and peritoneal branches. Massive and ongoing embolization of several eggs is unlikely.

Morphological studies conducted ${ }^{4}$, following the evolution of hepatic granulomas since their formation until long-lasting chronic forms, in patients who developed the chronic benign form, asymptomatic or oligosymptomatic, authors recommended classifying them in four phases: 1) granulomas in the necrotic-exudative phase; 2 ) in the exudative phase; 3 ) in the productive phase; and 4) in the fibrotic healing phase. Raso et al. ${ }^{6}$, concluded that, in humans, as well as in mice, acute forms of granulomas are significantly larger than those chronic forms. According to Andrade \& Warren ${ }^{8}$, and corroborated by other authors, it is correct to say that a decreased volume of granulomas is seen during the chronic phase of schistosomiasis.

Volume reduction and changes in histological aspects of granulomas start to show up during the acute phase of the disease. Between 43 and 70-78 days after infection, granulomas were shown to be in the necrotic-exudative phase, being large, coetaneous, with a generally extensive necrosis zone around an egg, and more externally a cellular exudation zone composed of macrophages, fibroblasts and lymphocytes. Granulomas with no necrosis zone are termed exudative granulomas and sometimes they are termed eosinophilic granulomas when polyomorphonuclear eosinophils prevail. In addition, according to these authors, in this phase, granulomas may be found with three distinct zones: 1 ) central with necrosis around the egg; 2 ) intermediate predominantly composed of epithelioid histiocytes forming a crown around the necrosis zone; and 3) a more external zone comprising a mixture of cells, with the predominance of eosinophilic granulocytes. The following phase, which starts around the $70^{\text {th }}-78^{\text {th }}$ day after infection, is when the granuloma undergoes changes in its size and constitution, and assumes the type of granulomas from the productive or fibrotic phase. This aspect between the productive phase and the fibrotic healing phase is thought to correspond to an intermediate or transitional phase between the chronic and the acute toxemic forms. After 9 to 18 months practically all granulomas were in the fibrotic healing phase, some of them were represented only by a scar.

In this work, recent granulomas (probably 30 to 40 days after egg deposition in the tissue) in the necrotic-exudative phase, similar to what was seen on the $78^{\text {th }}$ day of evolution of the acute toxemic form ${ }^{4}$, were in the necrosis zone (zone 1 ), sometimes vast, involving the embryonated egg, characterized by an amorphous eosinophilic material, known as Hoeppli phenomenon ${ }^{7}$, interspersed by thin fibers and a few fibroblast-like cells. Necrosis zone was generally less extensive than that commonly seen in the acute toxemic phase up to the $78^{\text {th }}$ day after infection. Some interpret it as the result of an $\mathrm{Ag}-\mathrm{Ac}$ reaction, as it depends on egg specific antigens (soluble egg antigens) which are highly immunogenic due to the presence of carbohydrate epitopes, LDN, LDN-F and LDN-DF ${ }^{16}$.

In time, zone 1, until then represented by necrosis, is gradually replaced by a fibrosis, originally loose and then dense, carried out by cells which are morphologically similar to fibroblasts. Therefore, they would account for centrifugal fibrosis, inside out, from the central zone which was previously represented by necrosis. Thin type III conjunctive fibers, stained in green by picrosirius, interspersing fibroblasts and histiocytes, at a later phase it is replaced by a homogeneous mass, little cellular, with few fibroblasts and histiocytes and finally by a compact 
dense fibrous nodule. These results seem to confirm what Al Adnani ${ }^{13}$ reported about the decrease in fibronectin due to the reduction or absence of cells able to produce it (macrophages and fibroblasts) ${ }^{15}$.

Around zone I of necrosis, a round wall is formed eminently cellular at first, composed mainly of epithelioid macrophages (zone II) which acts as a barrier trying to prevent the expansion of antigens secreted by the egg. These macrophages, at least in the beginning of the granuloma evolution (by around 70-78 days of acute form of infection), are epithelioid and tend to lie in palisade arrangement around zone I, forming a round mantle, which acts as a wall, preventing the egg antigen diffusion. About the $78^{\text {th }}$ day of infection (in the acute phase), as it also occurs in the chronic phase, some fuse to form giant Langhans or foreign body cells formation which try to involve and/or comprise the egg, sometimes reduced to a wizened shell, with no miracidium and no power of secretion.

In time, the wall, which was prominently cellular, is replaced by a practically acellular compact formation, comprising predominantly type 1 collagen fibers, with a variable thickness, composed of round and parallel fibers. This collagen is thought to be produced in this intermediate zone 2 , by epithelioid macrophages. These morphological data explain findings of Linder et al. ${ }^{15}$ i.e., the absence of fibronectin from the decrease or absence of cells (macrophages and fibroblasts) producing this protein glycoprotein. We may consider that this range, initially cellular and then practically fibrous and acellular, continues to act as a barrier to the diffusion of SEA antigens, with the purpose of limiting the lesion, mainly in granulomas with more time of evolution.

According to our experience, the external zone (zone 3 ) is well delineated after $120-150$ days of infection ${ }^{4}$. It is mainly formed by type I collagen fibers and a smaller amount of collagen type 3 , forming thicker fibers, which are parallel and round, with a few interposed and interwoven cells (connected by links similar to those of a chain) or resembling druses in onion scales, externally involving zone 2 . In smaller and older granulomas when zone 2 tends to disappear, it may directly involve zone 1 . According to our findings, zone 3 is produced by fibroblasts, with a possible participation of other cells characteristic from the conjunctive tissue or which migrate to the focus and which are present in recent granulomas.

In this case, the pseudotumoral form is associated with the hepatointestinal form of schistosomiasis. Furthermore, our results clearly demonstrate the modulation of immunopathological response and that the signs and symptoms of the pseudotumoral form of the disease disappeared with the chemotherapy (prazinquantel).

Modulation of granulomatous response was extensively investigated in mice. In 1964, Andrade \& Warren ${ }^{8}$ demonstrated a decrease in the size of granulomas formed around Schistosoma mansoni eggs that occurs at the chronic phase of disease, as well as alterations in the cellular and non-cellular constituents which take part in this inflammatory process. This phenomenon in the decreased granuloma size observed in late infection has been called modulation or immunological modulation. The phenomenon seems to be dependent of cell-mediated immunity and has been corroborated by several other authors, as it can be seen in Boros' review ${ }^{17}$.

Appearance and size of granulomas are very clearly described during transition from acute to chronic phases of human schistosomiasis in two papers: in the first, Raso \& Neves ${ }^{4}$ reported a histopathological study on 36 hepatic biopsy specimens from patients with acute toxemic form of schistosomiasis mansoni, describing in detail the evolution of the schistosomal granuloma from 21 to 250 days. In the second paper, Raso et al. ${ }^{5}$ described and measured 286 granulomas from patients with acute schistosomiasis and 165 granulomas from patients in chronic phase. In their papers Raso et al. ${ }^{5}$ clearly described the phenomenon of granuloma immunomodulation in humans infected with Schistosoma mansoni. Authors were able to define, in humans, the time of appearance, development and transformation from one to another of the four basic morphological types of granuloma (granuloma in necrotic-exudative phase, in the exudative phase, in the productive phase and in the cure by fibrosis). In 1976 Raso et al. ${ }^{5}$ were able to conclude that: a) granulomas show diverse development phases due to structural changes that occur during the evolution of the disease; b) granuloma size varies depending on the tissue or the organ where it is formed. It is larger in the liver, for example, than in the pancreas, intestines or testicles, etc.; c) there is a clear variation in size according to the stage of disease. They are much larger in the acute phase than in the chronic phase. As the disease progresses, there is an increasing tendency towards reduced volume; e) granuloma in humans, is much more developed than in experimental animals; $f$ ) granuloma falls under the influence of immunosupressants.

There is, without doubt, replacement by connective tissue as time passes, until the transformation of granulomatous lesion to a dense, compact nodule in the liver and in other organs is complete. This replacement may go on for months or years.

Modulation of granulomatous response starts around 70-78 days after infection, and concludes, in some cases, within 150-day infection, when it is indistinguishable from other chronic forms $\mathrm{s}^{4,5}$.

An extremely important observation was provided by anatomopathological study of 12 cases of acute toxemic schistosomiasis, necropsied at the Department of Pathology of Faculty of Medicine, Universidade Federal de Minas Gerais, in the 1950s-1970s by Bogliolo (4 cases) and Raso (8 cases). Granulomas of the liver, intestines, lungs, lymph nodes, etc. were maintained for a long time in the initial phase of development, in the necrotic-exudative phase. They were large granulomas with an extensive necrosis area around of the eggs, indicating an absence or a retardation of immunomodulation. This led one of us (Raso) to conclude that the cases with no modulation of granulomas evolved toward a fatal outcome. The same seems to have happened in the case recently described by Ferreira et al., 2012 of an acute form (Katayama syndrome) associated with Symmers form ${ }^{17}$. Rather, the majority of patients who had serial biopsies immunomodulation of granulomas evolved as wells to healing, regardless of treatment administered.

In the acute form, an immunological imbalance is proved by changes in the cytokine profile ${ }^{19}$.

On the other hand, a serial study on liver puncture-biopsies led us to conclude that in cases of modulation of granulomatous response, until the phase of cure by fibrosis, developed well: for one of the chronic forms or for a possible spontaneous cure, as it was observed in three cases, 13 years after the manifestations of acute toxemic form ${ }^{20}$.

In the present case, we may state that there is no significant in the morphology of the granuloma of the peritoneum and of the wall of the colon. Modulation of the immune response occurred in both as well as it occurred in the liver. 
As time goes time, both the human and in the experimental schistosomiasis have a decreased in the size of the granulomas and its replacement by fibrosis. In humans, fibrosis is predominantly consisted of type 1 collagen fibers; in mice, type 3 collagen fibers predominate. A total of 1,170 granulomas were measured on the $60^{\text {th }}$ day after infection and were shown to have a larger size than those measured on the $90^{\text {th }}$ day. Modulation of the immunological response was significantly more efficient for LE strain-infected mice than for those infected with SJ strain. The granulomas related to SJ were significantly larger (on the $60^{\text {th }}$ and $90^{\text {th }}$ days after infection) ${ }^{22}$.

Finally, in humans, unlike the claim Silva et al. in mice ${ }^{21}$, the immunomodulation occurs also outside of the liver (Figure 2).
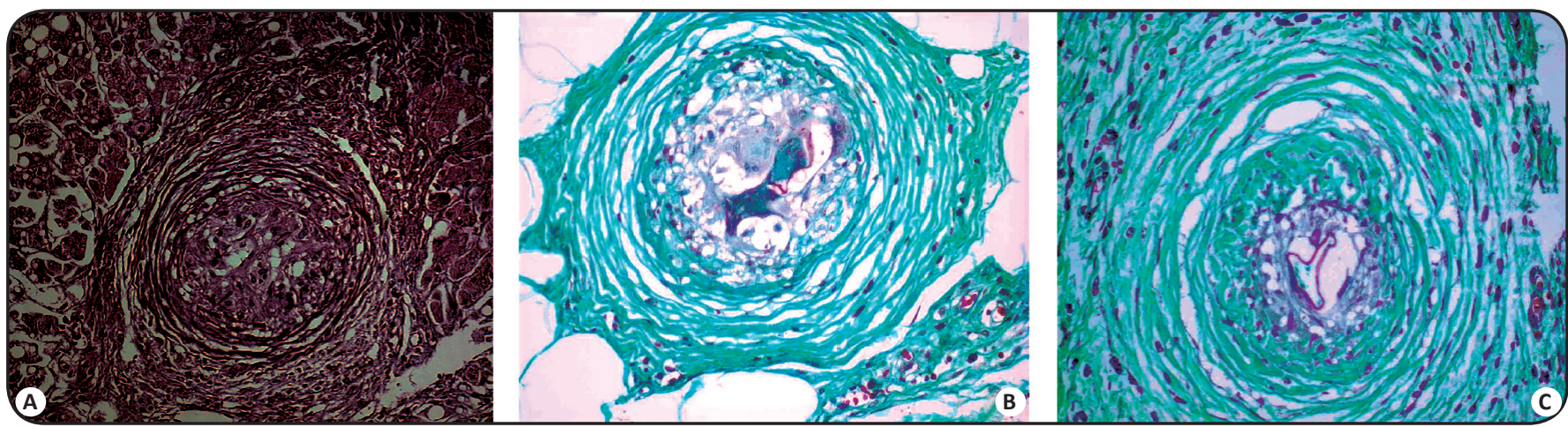

FIGURE 2 - Granuloma in fibrotic healing phase, with external zone (Z3) delineated by parallel and circular connective fibers, stained by HE in liver (A), and stained by trichromic in large intestine (B) and from peritoneum (C) as a result of modulation, in the same individual, with pseudotumoral form of schistosomiasis mansoni.

\section{ACKNOWLEDGMENTS}

To Carolina Dias for the English version.

\section{CONFLICT OF INTEREST}

The authors declare that there is no conflict of interest.

\section{ABSTRACT IN PORTUGUESE}

\section{Granuloma equistossomótico em fase evolutiva tardia, em um caso de forma tumoral no homem}

Introdução: Os autores descrevem o granuloma esquistossomótico no homem, na fase crônica tardia, do ponto de vista morfológico e evolutivo. Métodos: $O$ estudo baseou-se na análise histológica de dois fragmentos obtidos de biópsia cirúrgica do peritônio e do intestino grosso de um paciente de 42 anos de idade, com a forma pseudotumoral mimetizando carcinomatose peritoneal associada à forma hepatointestinal da esquistossomose. Resultados: Foram identificados 203 granulomas no pseudotumor e 27 na biópsia intestinal, com aspectos morfológicos semelhantes, a maioria na fase crônica tardia, em cura por fibrose. Foi sugerida nova classificação estrutural para os granulomas: zona 1 (interna), zona 2 (intermediária) e zona 3 (externa). Conclusões: Considerando o granuloma como um todo, concluímos que, provavelmente, a fibrose é comandada por mecanismos diferentes e independentes nas três zonas do granuloma. A fibrose lamelar na zona 3 parece ser comandada pelas células mesenquimais da matriz (fibroblastos e células mioepiteliais) e pelas células do exsudato inflamatório (linfócitos, plasmócitos, neutrófilos, eosinófilos). A fibrose anular na zona 2, composta por conjuntivo fibroso denso, pouco celular na fase avançada, seria comandada pelas células epitelioides que envolvem a zona 1 nos granulomas recentes. Na zona 1, substituindo a necrose periovular, a neoformação conjuntiva inicialmente frouxa, rendilhada, albergando células estreladas ou com núcleos fusiformes, surge um conjuntivo denso, paucicelular, nodular, provavelmente induzido pelos fibroblastos. Em muitos granulomas falta uma das zonas descritas e o granuloma é representado apenas por duas delas: Z3 e Z2, Z3 e Z1 ou Z2 e Z1 e, no final, por uma cicatriz.

Palavras-chaves: Equistossomose mansônica. Granuloma. Morfologia. Evolução e forma pseudotumoral. Modulação do granuloma.

\section{REFERENCES}

1. Zhu Y, Lukacs NW, Boros DL. Cloning of THO - and TH2 - type helper lymphocytes from liver granuloma of Schistosoma mansoni-infected mice. Infect Immunol 1944; 62:994-999.

2. Boros DL. Immunopathology of Schistosoma mansoni Infection. Clin Microbiol Reviews 1989; 2:250-269.

3. Mentik-Kane M, Cheever AW, Thompson RW, Hari DM, et al. IL-13 receptor alfa2 down-modulates granulomatous inflamation and prolongs host survival in schistosomiasis. Proc Acad Sci USA 2004; 102:586-590.

4. Raso P, Neves J. Contribuição ao conhecimento do quadro anatômico do fígado na forma toxêmica da esquistossomose mansoni através de punções-biópsias. An Fac Med Univ Fed Minas Gerais 1965; 22:147-195.

5. Raso P, Bernardes RC, Tafuri WL, Bogliolo L, Neves J. As dimensões do granuloma causado pelos ovos do S. mansoni no fígado humano. Rev Soc Bras Med Trop 1976; 12:45-49.

6. Raso P, Bogliolo L. Patologia. In: Cunha AS, editor. São Paulo: Savier - Editora da Universidade de São Paulo 1970; p. 70-130.

7. Raso P. Esquistossomose mansônica. In: Bogliolo Patologia. Brasileiro Filho G, editor. 7ạ ed. Editora Guanabara Koogan, 2006; p. 1337-1359.

8. Andrade ZA, Warren KS. Mild prolonged schistosomiasis in mice: alterations in host response with time and the development of portal fibrosis. Trans R Soc Trop Med Hyg 1964; 58:53-57.

9. Coelho PMZ, Raso P, Mello RT, Toppa NH. Schistosoma mansoni in mice: modulation of granulomatous response after reinfection and chemotherapeutic treatment. Rev Soc Bras Med Trop 1994; 27:119-125.

10. Lenzi HL, Romanha WS, Machado MP, Mota EM, Lenzi JA. Patologia experimental com enfoque no granuloma esquistossomótico: uma visão multidisciplinar. Carvalho OS et al., Organizadores. Rio de Janeiro: Editora Fundação Oswaldo Cruz 2008; p. 569-654.

11. Junqueira LCV, Bignolas G, Brentani R. Picrosirino staining plus polarization microscopy, a specific method for collagen detection in tissues sections. Histochem J 1979; 11:47-54.

12. Smith JH, Lichtemberg FV. The Hoepply phenomenon in schistosomiasis II. Histochemistry. Am J Pathol 1967; 50:993-1007.

13. Al Adnani MS. Concomitant immunohistochemical localization of fibronectin and collagen in schistosome granulomata. J Pathol 1985; 147:77-85.

14. Yamada KM, Olden K. Fibronectins-adhesive glycoproteins os cell surface and blood. Nature 1978; 275:179-184.

15. Linder $E$, Steman S, Lehto VP, Vaheri A. Distribuition of fibronectin in human tissues and relationship to other connective tissue components. Ann NY Acad Sci 1978; 312:151-159. 
16. van Die I, Cummings RD. Glycans modulate immune responses in helmintic infeccions helmintic infeccious and allergy. Chem Immunol Allergy 2006; 90:91-112.

17. Ferreira CR, Campos FPF, Martines JAS, Kim EIM, Smeili LAA. Schistosomiasis: a case of severe infection with fatal outcome. Autopsy Case Rep 2012; 2:1-17.

18. Bogliolo L. Subsidio para o estudo da Anatomia Patológica da forma aguda toxêmica. Gen 1964; 19:157-236.

19. Jesus AR, Silva A, Santana LB. Clinical and immunologic evaluation of 31 patients with acute schistosomiasis mansoni. J Infect Dis 2002; 185:98-105.
20. Raso P, Neves J, Bogliolo L, Tafuri WL, Pedroso ERP. A possível cura espontânea da esquistossomose mansoni humana: follow-up de três pacientes 13 anos após as manifestações da forma aguda toxêmica - nota prévia. Rev Soc Bras Med Trop 1978; 12:59-65.

21. Silva LM, Fernandes ALM, Barbosa JRA, Andrade ZA. Significance of schistosomal granuloma modulation. Mem Inst Oswaldo Cruz, Rio de Janeiro, 2000; 95:353-361.

22. Coelho PMZ, Raso P, Mello RT, Toppa NH. Dimenções do granuloma hepático produzido por ovos de duas linhagens geográficas no Schistosoma mansoni, no camundongo. Mem Inst Oswaldo Cruz, Rio de Janeiro, 1989; 84:213-217. 